\title{
Sistem Informasi Manajemen Pemesanan Usaha Katering Panti Asuhan Putri Aisyiyah Malang
}

\author{
Eka Larasati Amalia*,1, Mustika Mentari ${ }^{2}$, Vivin Ayu Lestari ${ }^{3}$, Farida Ulfa ${ }^{4}$, Vivi Nur Wijayaningrum ${ }^{5}$, \\ Widiareta Safitri $^{6}$, Naufal Yukafi Ridlo ${ }^{7}$, Nabilah Argyanti Ardyningrum ${ }^{8}$ \\ 1,2,3,4,5,6,7,8 Jurusan Teknologi Informasi, Politeknik Negeri Malang \\ e-mail: *11eka.larasati@polinema.ac.id, ${ }^{2}$ must.mentari@polinema.ac.id, ${ }^{3}$ vivinlestari91@gmail.com, \\ 4faridaulfa@polinema.ac.id, ${ }^{5}$ vivinurw@polinema.ac.id, ${ }^{6}$ wretasafitri33@gmail.com,. naufalyukafi10@gmail.com, \\ 8nargyanti@gmail.com
}

\begin{abstract}
Abstrak
Pembekalan keterampilan pada anak-anak di Panti Asuhan merupakan sebuah hal penting yang dapat digunakan sebagai bekal masa depan. Panti Asuhan Putri Aisyiyah Malang memberikan bekal keterampilan berwirausaha bagi anak asuhnya melalui usaha katering bernama PAP'A. Seiring berkembangnya usaha katering $P A P^{\prime} A$ tersebut, jangkauan pelanggan yang melakukan pemesanan juga semakin bertambah, sehingga diperlukan adanya manajemen pemesanan yang baik. Sayangnya, katering PAP'A tidak memanfaatkan teknologi untuk melakukan manajemen pemesanan yang dilakukan oleh pelanggan. Mereka hanya mencatat transaksi pemesanan yang dilakukan melalui telepon, WhatsApp, atau SMS ke dalam sebuah buku. Hal inilah yang menyebabkan seringnya terjadi human error dan berimbas pada kerugian di pihak pelanggan maupun pihak katering PAP'A. Oleh karena itu, pada kegiatan pengabdian kepada masyarakat ini, diusulkan sebuah sistem informasi dalam bentuk website yang dikembangkan untuk memudahkan pihak katering PAP'A dalam melakukan manajemen pemesanan. Dengan adanya sistem informasi ini, pihak katering PAP'A dapat melakukan pengelolaan daftar pesanan, daftar produk makanan, dan pembayaran secara lebih terstruktur. Adanya fitur pembayaran juga memberikan kemudahan bagi pihak katering $P A P^{\prime} A$ untuk menghasilkan nota bukti pembayaran yang dilakukan oleh pelanggan.
\end{abstract}

Kata kunci—kewirausahaan, panti asuhan, sistem informasi, teknologi

\section{PENDAHULUAN}

Panti Asuhan merupakan sebuah lembaga yang bergerak di bidang kesejahteraan sosial dan dikelola oleh sebuah Yayasan [1]. Tugas utama dari sebuah Panti Asuhan adalah bertanggung jawab untuk memberikan pelayanan kepada anak-anak yatim piatu, anak-anak yang kurang mampu secara finansial, dan anak terlantar demi terjaminnya kesejahteraan sosial mereka. Pelayanan yang diberikan oleh Panti Asuhan dapat berupa proses pengasuhan, perlindungan, bimbingan, dan kegiatan lainnya termasuk pendidikan dan pembentukan karakter anak-anak asuh yang berada di Panti Asuhan tersebut [2][3]. Anak-anak asuh akan diasramakan dan diberikan pembinaan di Panti Asuhan dalam bentuk pelayanan pendidikan formal, keagamaan, dan kewirausahaan [4][5]. Pembekalan kewirausahaan diperlukan bagi anak-anak asuh agar mereka dapat hidup secara mandiri setelah lepas dari yayasan. Hal ini dikarenakan mereka dituntut untuk mandiri secara finansial setelah umur mereka menginjak 18 tahun atau setara dengan lulus Sekolah Menengah Atas [6][7].

Seiring dengan berkembangnya teknologi, maka tentunya setiap orang harus mampu menyesuaikan diri dan mengembangkan potensi diri yang dimilikinya agar dapat menjadi pribadi yang kompetitif sehingga dapat bersaing di era globalisasi saat ini [8][9].

Panti asuhan Putri Aisyiyah Malang telah memiliki donatur tetap, tetapi diperlukan usaha mandiri yang dapat dipergunakan untuk sumber penghasilan Panti Asuhan selain dari para donatur tetap tersebut dengan menginisiasi pembukaan usaha katering. Analisis situasi yang akhirnya menghasilkan ide Pengabdian Pada Masyarakat ini dapat dilihati dari 3 sisi yaitu, dari sisi Panti Asuhan Aisiyah Malang (PAP'A), sisi masyarakat umum, ataupun orang-orang yang terlibat dalam usaha catering PAP'A ini. Analisis situasi jika dilihat dari sisi panti asuhan dapt dilihat bahwa usaha catering ini selain menjadi sumber pengahasilan tambahan 
sekaligus menjadi bekal bagi anak-anak untuk menempuh pendidikan dan dapat membuka usaha sendiri. Selain itu, usaha katering PAP'A ini juga mempunyai beberapa pegawai yang berasal dari masyarakat di sekitar wilayah panti asuhan, terutama ibu rumah tangga yang tidak mempunyai pekerjaan tetap, termasuk para janda yang harus membiayai kehidupan keluarga mereka, serta memastikan anakanak mereka tetap dapat bersekolah.

Dengan berkembangnya usaha katering PAP'A, jenis makanan yang ditawarkan menjadi semakin banyak, meliputi kue basah, nasi kotak, tumpeng dan prasamanan, serta kue untuk oleh-oleh. Jangkauan pelanggan yang memesan produk-produk katering PAP'A juga semakin luas, mulai dari sekolah dan universitas untuk kegiatan-kegiatan resmi, hingga rumah sakit untuk konsumsi pasien yang sedang dirawat. Hal ini yang menyebabkan katering PAP'A mendapatkan pesanan yang cukup banyak dari berbagai pelanggan setiap harinya.

Jika dilihat dari analisis situasi masyarakat umum khususnya konsumen atau pelanggan terdapat beberapa permasalahan yang membutuhkan solusi. Saat ini, pemesanan katering hanya dapat dilakukan melalui chat dengan aplikasi WhatsApp, SMS, telepon, ataupun pelanggan datang secara langsung ke lokasi panti asuhan. Kemudian sering terjadi kehilangan nota rekapan sehingga mempersulit penelusuran tentang data pemesanan, dan juga dibutuhkannya tambahan notifikasi pemberitahuan mengenai pesanan mana yang sudah mendekati hari pengiriman. dan berbagai permasalahan lainnya yang menyebabkan berkurangnya kepuasan pelanggan.

Analisis situasi ketiga dijelaskan berdasarkan peran orang-orang yang terlibat dalam usaha katering PAP'A. Terdapat lebih dari satu operator pada usaha katering ini, operator juga bertindak sebagai pembuat kue sekaligus terkadang harus melakukan pengantaran kue juga ke konsumen. Karena pekerjaan yang cukup padat dan setiap pegawai dapat memiliki peran ganda, maka berbeda orang yang melayani bisa saja terjadi kesalahan yang tidak terduga. Selain itu pencatatan yang serba menggunakan kertas akan rawan terhadap data hilang dan sulit dalam penelusuran. Maka untuk mengurangi tingkat kesalahan pencatatan serta manajemen pemesanan yang selama ini mengandalkan kertas dibutuhkan sistem informasi yang dapat melakukan pencatatan ataupun manajemen pemesanan secara digital dan terpusat.

Berdasarkan permasalahan yang dihadapi oleh katering PAP'A yang dikelola oleh Panti Asuhan Putri Aisyiyah tersebut, maka kegiatan pengabdian pada masyarakat dilakukan dalam bentuk pembuatan sebuah sistem informasi untuk manajemen pemesanan usaha katering PAP'A. Selain itu, kegiatan pelatihan juga dilakukan untuk pegawai administrasi yang bertugas untuk melakukan pencatatan pemesanan agar dapat menggunakan sistem informasi yang dikembangkan tanpa mengalami kendala. Dengan adanya sistem informasi ini, diharapkan aktivitas penjualan di katering PAP'A dapat menjadi lebih mudah, terhindar dari kesalahankesalahan yang berupa human error, sehingga PAP'A tetap dapat mempertahankan kualitas produk dan pelayanan yang diberikan kepada pelanggan.

\section{METODE}

Terdapat beberapa tahapan dalam menyelesaikan permasalahan mitra adalah sebagai berikut:

1) Observasi lapangan

2) Identifikasi permasalahan dan kelemahan mitra

3) Penawaran solusi pada mitra

4) Perancangan sistem

5) Implementasi sistem

6) Pengujian sistem

7) Sosialisasi penggunaan sistem

Metode pelaksanaan digunakan dalam pengabdian pada masyarakat ini ditunjukkan pada Gambar 1.

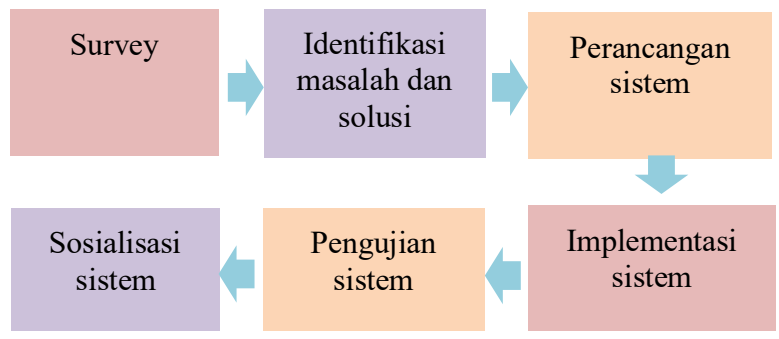

Gambar 1 Metode pelaksanaan

\subsection{Survey}

Dalam tahap survei, dilakukan kunjungan ke lokasi mitra untuk melakukan observasi/mencari tahu permasalahan yang ada di mitra, yaitu Panti Asuhan Putri Aisyiyah Malang (PAP'A), yang ditunjukkan pada Gambar 2. 


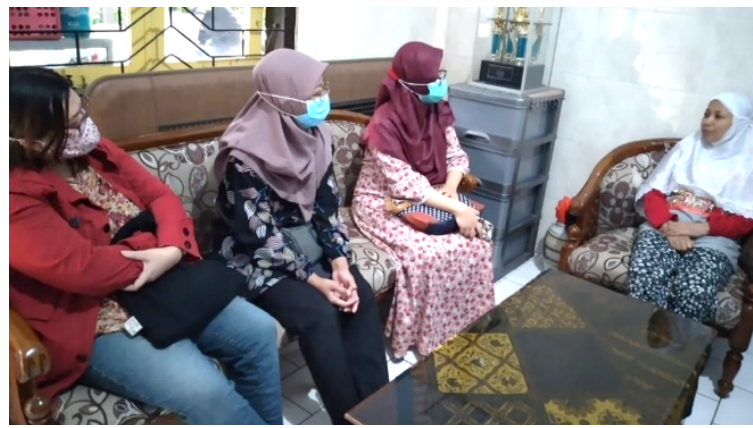

Gambar 2 Survei ke Panti Asuhan

Berdasarkan hasil survey, diketahui bahwa PAP'A saat ini belum mempunyai sistem yang dapat membantu dalam pemesanan dan notifikasi katering, pencarian data, serta pengelolaan nota masih dilakukan secara manual tanpa sebuah sistem yang terkomputerisasi. Hal ini dapat menyebabkan adanya peluang kehilangan data, kesalahan pendataan dan penyampaian informasi, serta dapat mengganggu operasional penjualan dan dapat mengalami kerugian. Pengelolaan data secara manual menyebabkan data tidak akurat dan tepat karena tidak terkomputerisasi dan pula tidak menggunakan database sebagai media pengimpanan data [10].

Proses pemesanan katering saat ini masih menggunakan aplikasi via Whatsapp dan pencarian data masih menggunakan buku. Cara seperti ini tentu membutuhkan tenaga dan waktu yang lebih, sehingga PAP'A membutuhkan sistem informasi yang dapat membantu dalam pemesanan katering, mengolah data yang baik dan penyampaian informasi secara digital.

\subsection{Perancangan Sistem}

Sistem informasi manajemen pemesanan dirancang menggunakan diagram use case, desain database, dan juga desain user interface. Dalam rancangan tersebut akan memperhatikan dua peran utama yaitu kasir dan juga admin.

Admin memiliki spesifikasi dalam pengelolaan data-data yang ada termasuk data akun dan juga semua data yang melibatkan pemesanan di katering PAP'A. Selain itu kasir mendapatkan peran mutlak terkait masalah pemesanan dan juga pembayaran.

\subsection{Implementasi Sistem}

Implementasi sistem informasi manajemen pemesanan telah disesuaikan dengan rancangan yang telah dibuat berbasis website. Tampilan website sistem informasi manajemen pemesanan dimulai dari tampilan awal yaitu login user, dan juga menu-menu atau fitur-fitur yang dibuat. Fitur-fitur tersebut meliputi:

1) Pengelolaan pemesanan a. Daftar produk

b. Daftar pesanan

2) Pengelolaan Pembayaran

3) Pengelolaan akun

4) Pengelolaan daftar produk

\section{HASIL DAN PEMBAHASAN}

Sistem informasi PAP'A Catering merupakan aplikasi berbasis website yang bertujuan untuk memanajemen pemesanan katering untuk usaha katering PAP'A Catering.

\subsection{Perangkat Lunak}

Perangkat lunak yang digunakan untuk menjalankan website PAP'A Catering adalah:

- Operating System untuk perangkat dekstop seperti Windows, Linux, atau MacOS

- Web browser, seperti Google Chrome, Mozilla Firefox, dan Safari.

\subsection{Perangkat Keras}

Perangkat keras yang dibutuhkan untuk menjalankan website PAP'A Catering adalah sebagai berikut:

- Komputer / Laptop

- Mouse

- Keyboard

- Printer

\subsection{Rancangan Sistem}

Rancangan sistem berupa use case dapat dilihat pada Gambar 3. Aplikasi berupa website dibangun untuk dua pengguna yaitu admin dan kasir. Admin bertanggung jawab pada pengelolaan akun kasir dan data produk, sedangkan kasir bertugas mengelola aktivitas pembayaran dan pemesanan.

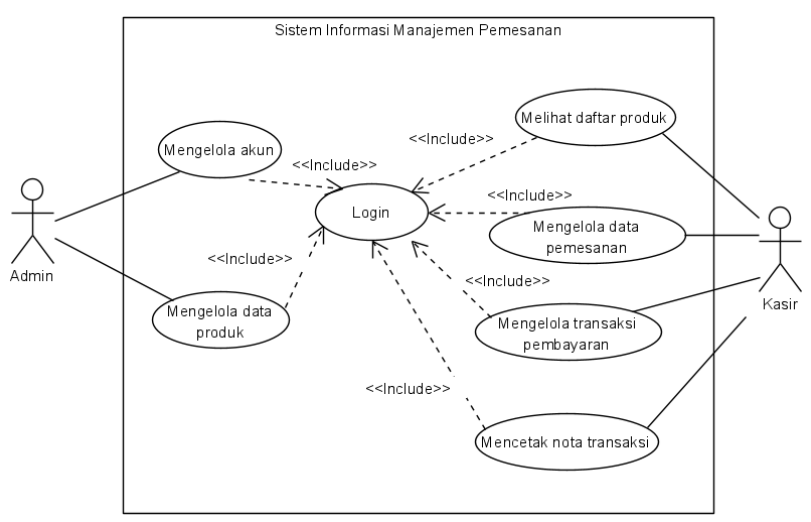

Gambar 3 Use Case Sistem 


\subsection{Tampilan Sistem Informasi}

Sistem informasi PAP'A Catering terdiri dari beberapa tampilan halaman yang masing-masing mempunyai fungsi penggunaan sesuai dengan solusi penyelesaian permasalahan.

\subsubsection{Halaman Login}

Gambar 4 di bawah ini merupakan tampilan halaman login. Setelah melakukan login, pengguna akan diarahkan ke halaman utama yang berisi daftar pemesanan.

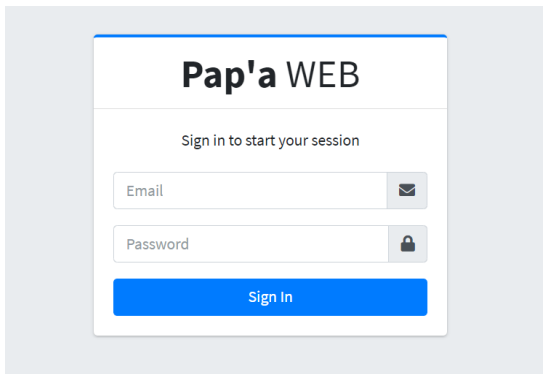

Gambar 4 Halaman Login

\subsubsection{Halaman Daftar Pemesanan}

Halaman daftar pemesanan ini merupakan halaman utama setelah pengguna login ke dalam website. Pada halaman ini, terdapat nomor nota, nama pemesan, tanggal order, tanggal kirim, jam kirim, status pembayaran, status pengiriman dan metode pengiriman. Gambar 5 merupakan halaman daftar pemesanan.

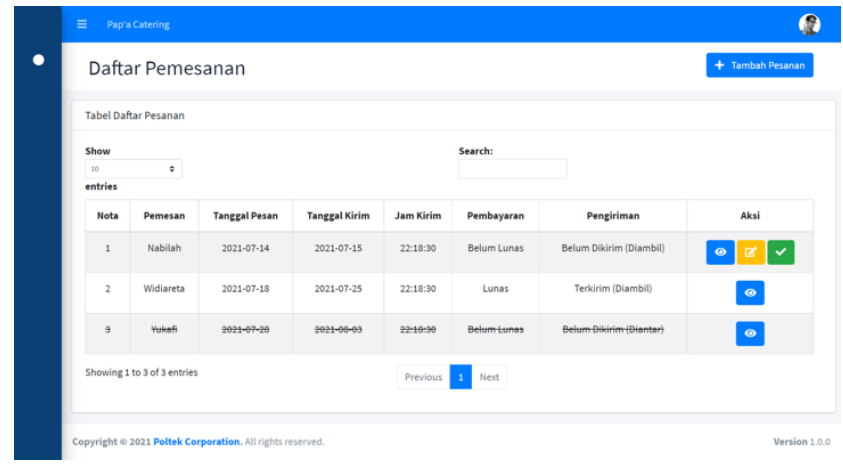

Gambar 5 Halaman Daftar Pemesanan

\subsubsection{Halaman Detail Pemesanan}

Pada halaman ini, terlihat detail dari pemesanan yang dilakukan oleh seorang konsumen. Selain itu terdapat metode pengiriman, biaya pengiriman, dan total pemesanan yang harus dibayarkan. Gambar 6 merupakan halaman detail pemesanan.
Detail Pemesanan

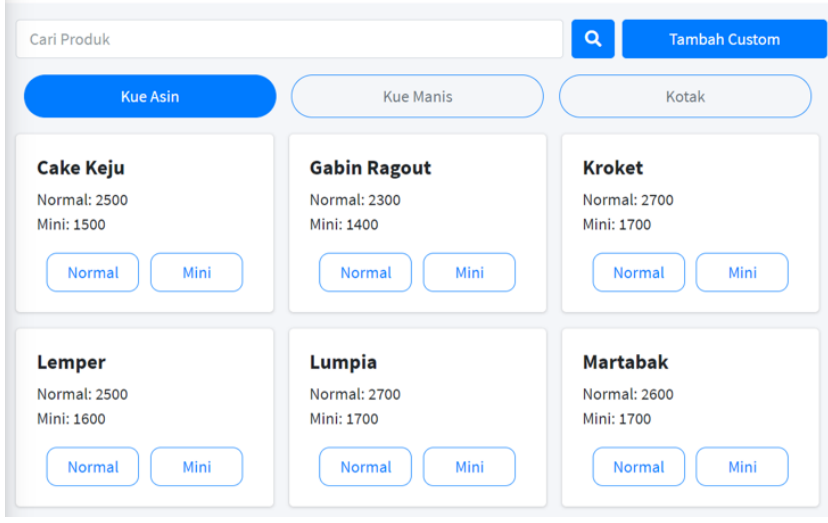

Gambar 6 Halaman Detail Pemesanan

\subsubsection{Halaman Keranjang Belanja}

Produk yang sudah dipesan dapat dilihat pada keranjang belanja. Keranjang belanja menampilkan daftar produk yang akan dipesan. Gambar 7 merupakan halaman keranjang belanja.

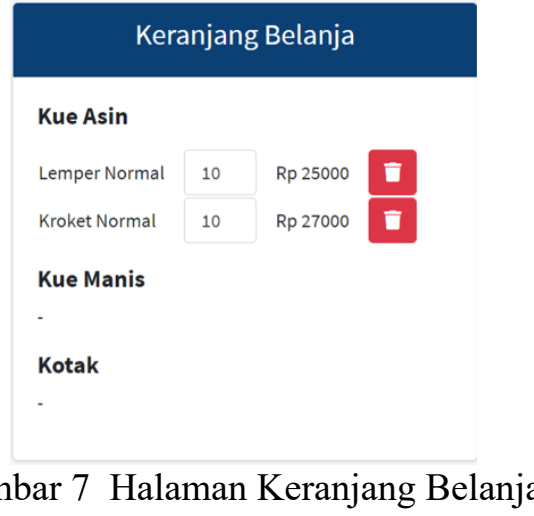

\subsubsection{Tampilan Konfirmasi Pembayaran}

Jika pembayaran belum lunas atau pesanan belum terkirim, maka akan muncul penanda bahwa pemesanan belum bisa ditandai sebagai selesai dikarenakan pembayaran yang belum lunas atau pesanan belum terkirim. Halaman tersebut dapat dilihat pada Gambar 8. Apabila pemesan sudah membayar pesanan dengan lunas dan pesanan katering sudah dikirim, maka pemesanan dapat ditandai sebagai lunas. Pemesanan yang sudah selesai ditandai dengan tidak adanya tombol centang dan tombol edit pemesanan. Halaman tersebut dapat dilihat pada Gambar 9.

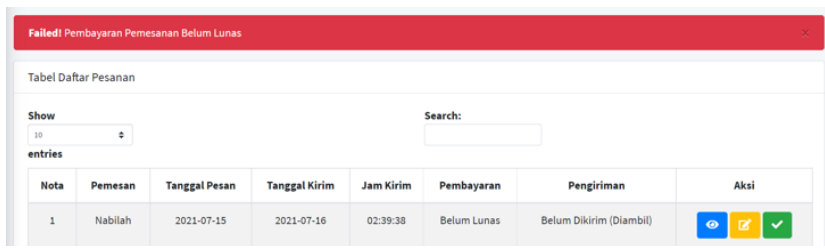


Gambar 8 Kofirmasi Pembayaran Belum Lunas

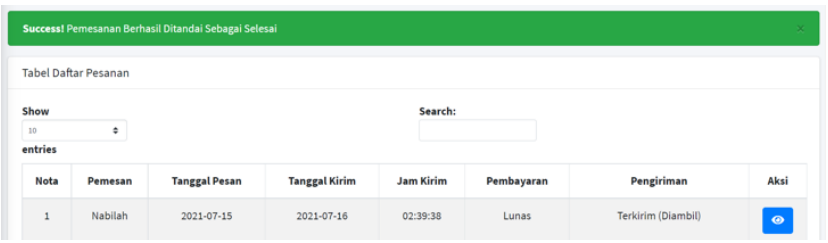

Gambar 9 Kofirmasi Pembayaran Lunas

\subsubsection{Halaman Nota Pemesanan}

Nota pemesanan merupakan bukti transaksi yang dapat diakses setelah proses pemesanan dilakukan. Gambar 10 dan Gambar 11 merupakan halaman nota pemesanan dan cetak nota keseluruhan beserta data pembayaran oleh pelanggan.

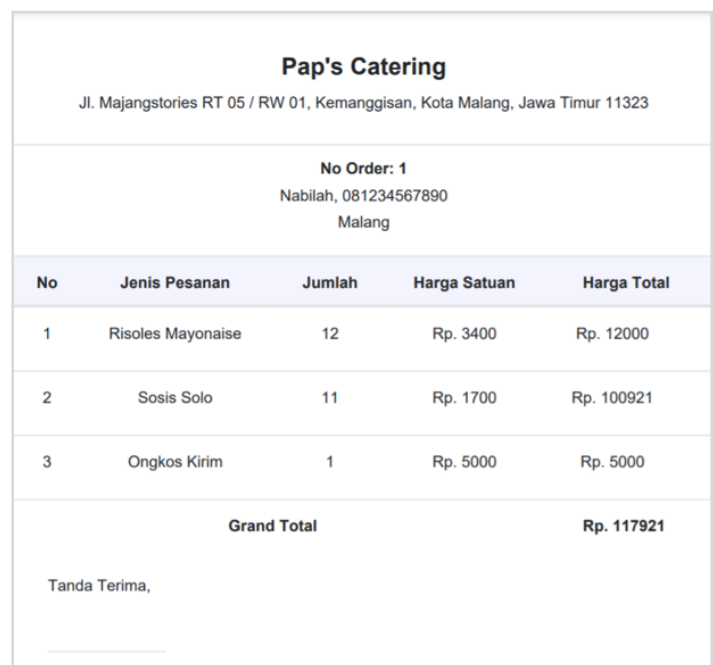

Gambar 10 Halaman nota pemesanan

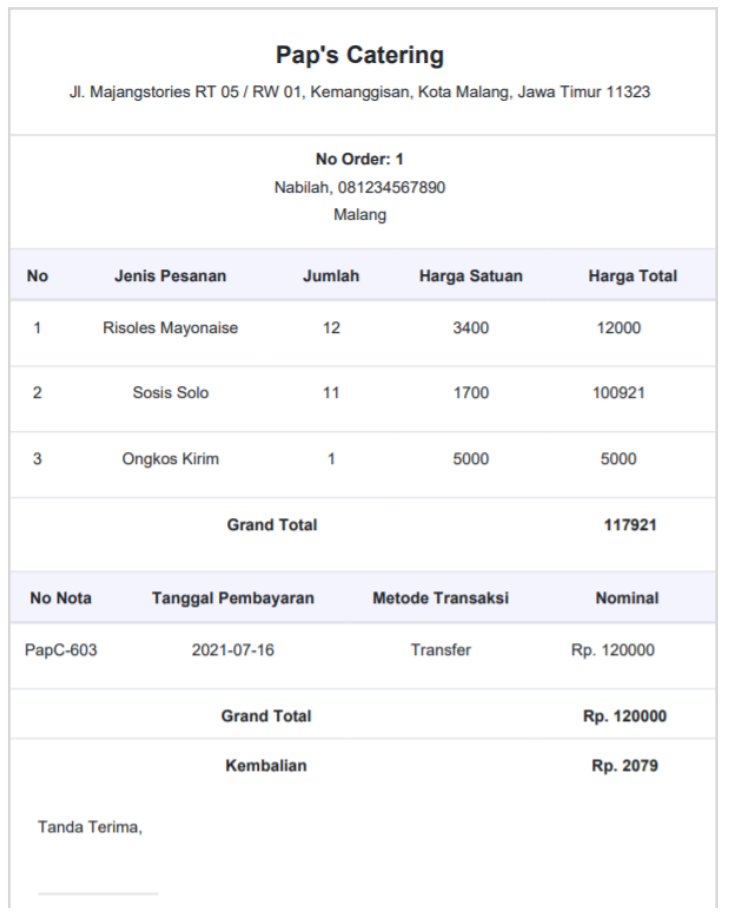

Gambar 11 Halaman nota keseluruhan

\subsection{Pasca Pengembangan Website}

Setelah melakukan pengembangan, website sistem informasi ini diuji untuk mengukur fungsionalitas dari sistem sebelum dirilis dan digunakan oleh mitra. Selanjutnya, dilakukan pembuatan buku pedoman penggunaan website sistem informasi. Buku pedoman ini diharapkan dapat menjadi acuan bagi pengguna dan operator PAP'A Catering dalam mengoperasionalkan website. Selain itu, pelatihan pengelolaan serta pemanfaatan website untuk mendukung aktivitas usaha sehari-hari juga dilakukan bersama dengan tim pengembangan. Khalayak sasaran yang dilibatkan dalam kegiatan ini adalah pengurus aktif dari Panti Asuhan Putri Aisyiyah Malang.

\section{KESIMPULAN}

Kegiatan pengembangan Sistem Informasi Manajemen Pemesanan Usaha Katering di Panti Asuhan Putri Aisyiyah Malang terbagi menjadi 2 sub kegiatan. Kegiatan pertama adalah pengembangan Sistem Informasi Manajemen Pemesanan Usaha Katering untuk Panti Asuhan Putri Aisyiyah Malang. Selanjutnya adalah kegiatan pelatihan untuk penggunaan sistem itu sendiri.

Dari segi pengembangan sistem informasi, PAP'A Catering merupakan aplikasi berbasis website yang bertujuan untuk membantu manajemen pemesanan katering untuk usaha katering PAP'A Catering. Sistem ini juga dilengkapi dengan Manual Book yang nantinya bisa digunakan sebagai user manual untuk membantu mengoperasikan sistem ini.

Selanjutnya dari segi pelaksanaan pelatihan itu sendiri, dengan adanya keterbatasan pelaksanaan yang dikarenakan Pandemi COVID-19 pada awal Maret 2020 dan berlanjut hingga saat ini, maka program pengabdian ini yang semula berencana mengadakan acara pelatihan offline di Panti Asuhan Putri Aisyiyah Malang (PAP'A), Malang akhirnya terhambat dan dilaksanakan secara online pada bulan Juni 2020 dan dimulai dari pukul 08.00-13.00. Peserta merupakan pengurus dan pelaksana usaha di panti asuhan tersebut. Kegiatan pengabdian ini memberikan bimbingan teknis berupa cara pemanfaatan sistem operasi yang telah dibangun agar perangkat tersebut dapat membantu pihak panti asuhan sehingga pada akhirnya nanti para peserta pelatihan tersebut dapat menerapkannya untuk kebutuhan manajemen catering PAP'A sehari-hari. 


\section{SARAN}

Saran dari kegiatan pengabdian pada masyarakat ini adalah sebagai berikut:

1. Para peserta pelatihan perlu diberikan pendalaman materi lebih matang lagi untuk penggunaan sistem informasi yang telah dibangun agar bisa mengaplikasikannya langsung dan berbagi pengetahuan tersebut dengan user lain dalam panti yang sama.

2. Sistem yang baik adalah sistem yang memiliki kebermanfaatan dan kerja sistem yang baik sehingga dapat dilakukan pengembangan aplikasi ini lebih lanjut.

3. Sistem dapat dikembangkan dengan versi Android untuk memudahkan pengguna dalam mengakses kapanpun dan dimanapun.

4. Penambahan fitur lain untuk keperluan manajemen catering agar lebih lengkap.

5. Manajemen akun pada aplikasi ini bisa lebih disempurnakan.

\section{UCAPAN TERIMA KASIH}

Penulis mengucapkan terima kasih kepada Politeknik Negeri Malang yang telah memberikan dukungan moral dan dana terhadap program pengabdian masyarakat ini dan seluruh pengurus Panti Asuhan Putri Aisyiyah Malang yang mendukung terselenggaranya kegiatan pengabdian ini dengan baik dan lancer.

\section{DAFTAR PUSTAKA}

[1] Syawal, A., Manan, S., 2015, Peranan Panti Asuhan dalam Pembentukan Moral Anak (Studi pada Yayasan Panti Asuhan Bustanul Islamiyah, Kecamatan Panakukkang, Kota Makassar), J. Tomalebbi, No. 3, Vol. 2, pp. 32-39.

[2] Hukul, K., Siti, J., dan Saddam, H., 2019, Peran Pengasuh Panti Asuhan Yayasan Melati Alkhairat Ambon Dalam Meningkatkan Prestasi Belajar Anak Asuh, Kuttab J. Ilm. Mhs., No. 1, Vol. 1, pp. 33-42.

[3] Suseno, M.N., 2013, Efektivitas Pembentukan Karakter Spiritual Untuk Meningkatkan Optimisme Terhadap Masa Depan Anak Yatim Piatu, J. Interv. Psikol No. 1, Vol. 5, pp. 1-24.
Kelembagaan Panti Asuhan Untuk Membangun Kemandirian Finansial Melalui Pelatihan Kewirausahaan," J. Pengabdi. Masy. IPTEKS, No. 1, Vol. 6, pp. 1-8.

[5] Yuliasari, N.R., Sungkowo E.M., 2015, Perang Pengelola Panti Asuhan dalam Upaya Meningkatkan Kedisiplinan Anak Asuh (Studi Empiris Panti Asuhan Yatim Muhammadiyah Danukusumo Kabupaten Purworejo), J. Nonform. Educ. Community Empower., No. 2, Vol. 4, pp. 93-98.

[6] Isbanah, Y., Achmad, K., dan Prayudi, S.P., 2017, Membangun Kemandirian Financial Anak Panti Asuhan Melalui Pelatihan Kewirausahaan," J. Abdimas, No. 2, Vol. 21, pp. 153-160.

[7] Amaliah, T.H., Mattoasi, dan Agus, H.B., 2019, Pengembangan Social Enterpreneurship Berbasis Budaya Lokal Menuju Kemandirian pada Panti Asuhan Al Amanah Gorontalo, J. Ilm. Pangabdhi, No. 2, Vol. 5, pp. 75-84.

[8] Mubarok, Z., Didin, H., Henri, T. Dan Abas, M. T., 2018, Pendidikan Wirausaha bagi Anak Panti Asuhan Yatim Muhammadiyah dan Pengaruhnya Terhadap Kemandirian Anak, Ta'dibuna J. Pendidik. Islam, No. 2, Vol. 7, pp. 152-172.

[9] Herlina, E., 2013, Strategi Panti Asuhan dalam Meningkatkan Kemandirian Warga Belajar Melalui Pendidikan dan Pelatihan Kewirausahaan," Empower. J. Ilm. Progr. Stud. Pendidik. Luar Sekol., No. 2, Vol. 2, pp. 105-116.

[10] Azwanti, N., 2017, Sistem Informasi Penjualan Tas Berbasis Web dengan Pemodelan UML, Kumpul. J. Ilmu Komput., No. 1, Vol. 4, pp. 114.

[4] Angin, R., Baktiawan, N., 2020, Penguatan 